\title{
Corrosion Inhibitor of Carbon Steel from Onion Peel Extract
}

\author{
Asep Muhammad Samsudin ${ }^{1}$, Aribella Samudra Pamungkas ${ }^{1 *}$, and Ratih Estu Nugraheni ${ }^{1}$ \\ ${ }^{1}$ Chemical Engineering, Engineering Faculty, Diponegoro University, Indonesia.
}

\begin{abstract}
Carbon steels composed by two main elements, they are iron $(\mathrm{Fe})$ and carbon $(\mathrm{C})$ elements which widely used in industrial because of its resistance and more affordable than stainless steel, but their weakness is they have low corrosion resistance. One way to modify carbon steel is by coating them with antioxidant compounds that can delay, slow down, and prevent lipid oxidation process, which obtained from onion peel extract. Several studies on corrosion inhibitors have been performed. However, the efficiency was not reach the optimum. This study aims to examine the effect of onion peel extract concentration on the efficiency of corrosion inhibitor and characterization of the green corrosion inhibitor from onion peel extract. This research method begins by extracting onion peel to $200 \mathrm{ml}$ solvent which we use aquadest and methanol and mixed with 5 grams of crushed onion peel, then let them be extracted for 60 minutes with room temperature. Once it was filtered and the solution obtained, followed by evaporating process with rotary evaporator to decrease the content of solvent. The product is ready to be used as a green corrosion inhibitor of carbon steel in $1 \mathrm{~mol} / \mathrm{L} \mathrm{HCl}$. While the analysis used is HPLC qualitative analysis, and electroplatting process. The impedance is measured at a frequency of $100 \mathrm{kHz}$ to $4 \mathrm{mHz}$ with an $\mathrm{AC}$ current of $10 \mathrm{mV}$. Inhibitor concentrations are vary between $2 \mathrm{ml}$ and $4 \mathrm{ml}$ of onion peel extract. Electroplatting is done within 30 minutes with 10 minutes each checking time. Furthermore, quantitative analysis was done for the analysis of corrosion rate and weight loss. Based on HPLC analysis, it is known that the extract of onion peel contains $1 \mathrm{mg} / \mathrm{L}$ of quercetin, which is belong to flavonoid group as green inhibitor. While electroplatting process, aquadest solvent having average efficiency of $99,57 \%$ for $2 \mathrm{ml}$ of extract, and $99,60 \%$ for $4 \mathrm{ml}$ of extract. Methanol solvent having average efficiency of $99,52 \%$ for $2 \mathrm{ml}$ of extract and $99,74 \%$ for $4 \mathrm{ml}$ of extract. In line, methanol have more possibilities to gain flavonoid out to act as green inhibitor than aquadest due to its polarity. It is suggested to cover up the extract of onion peel to avoid them against sunlight, to keep the flavonoid not damaged.
\end{abstract}

\section{Introduction}

Metal element is one of the basic materials that can not be separated from human life. The metal whom most commonly used is carbon steel with the main content of iron $(\mathrm{Fe})$ and carbon $(\mathrm{C})$. The advantages of carbon steel are more affordable than stainless steel or other steel, but have weaknesses such as not corrosion resistant. The Gross National Product (GNP) survey shows in 2001 corrosion losses could exceed $\$ 600$ billion. Therefore it is necessary to do special treatment to reduce corrosion, including by coating carbon steel with corrosion inhibitor.

Corrosion inhibitors are chemicals that can decrease the corrosion rate of metals in contact with the environment. The corrosion inhibitor is divided into organic and inorganic inhibitors. Synthetic inhibitors come from hazardous chemicals, they are quite expensive, and are not environmentally friendly. So it is necessary another inhibitor that is safe, easy to obtain, biodegradable, cheap cost, and environmentally friendly [1].

Corrosion inhibitors should have antioxidant compounds that can donate one or more electrons to the prooxidant compound, then convert the oxidant compound into a more stable compound [2]. This compound can be found in nuts, vegetables, fruits, chocolate and tea [3].

onions peel contain active substances such as Allin, Flavonoid, Saponin, Petrin, and Allisin. Flavonols contained in onion peel are 270-1187 mg / kg, indicating that the flavonoid content is greater than garlic skin (89.3-101 mg/ kg) and red onion skin (98 $\mathrm{mg} / \mathrm{kg}$ ) [4]. Based on BPS and the Directorate of Horticulture, on 2015 the production of onions in Indonesia reaches about 10,000 tons, where the waste of leather is $10-15 \%$ or about $1000-1500$ tons of onion peel every year has not been fully utilized.

\section{Methodology}

\subsection{Material}

Onion peel, aquadest, hydrogen chloride $(\mathrm{HCl})$, carbon steel, methanol.

\subsection{Inhibitor Preparation}

$200 \mathrm{ml}$ of aquades mixed with 5 grams of onion peel that has been destroyed. Let stand 60 minutes, then separated between the pulp and solvent. Reduce the solvent with rotary evaporator. Perform this step again on methanol solvent. 


\subsection{Material Preparation}

Cut carbon steel of the same size $(5 \mathrm{~cm} \times 1 \mathrm{~cm})$. Then sanding carbon steel to remove impurities.

\subsection{Solution Preparation}

Mix $1 \mathrm{~mol} / \mathrm{L} \mathrm{HCl}$ on $100 \mathrm{ml}$ base. Then make an electrolyte solution with an onion peel concentration of $2 \mathrm{ml}$ and $4 \mathrm{ml}$ for each solvent.

\subsection{Electroplating Analysis}

Calculate weight of carbon steel, clean carbon steel surface, then do electroplating process. In this process, carbon steel is cathode pole, while zinc is anode pole. The electroplating process is carried out at an $\mathrm{AC}$ current of $10 \mathrm{mV}$.

\subsection{Efficiency Analysis}

Calculate weight of carbon steel before electroplating. Also calculate weight of carbon steel after electroplating for 10 minutes, 20 minutes, and 30 minutes. To calculate the efficiency of inhibitor corrosion can use formula of down below:

$$
\mathrm{n}=\frac{w_{0}-W}{w_{0}} \times 100 \%
$$

Where, $\mathrm{n}=$ efficiency $(\%)$, Wo $=$ weight of carbon steel before electoplating (gr), and $\mathrm{W}=$ weight of carbon steel after electoplating (gr)

\subsection{Morphological Analysis}

Morphological analysis was performed using HPLC to determine onion peel content.

\subsection{Analysis of Corrosion Rate}

Calculate different of weight carbon steel and surface area of the electroplating. To calculate corrosion rate use formula:

$$
\text { mpy }=\frac{534 . W}{D_{-A} \cdot \boldsymbol{t}}
$$

Where, $\mathrm{W}=$ weight loss $(\mathrm{mg}), \mathrm{D}=$ carbon steel density $\left(\mathrm{gr} / \mathrm{cm}^{3}\right), \mathrm{A}=$ surface area $\left(\mathrm{in}^{2}\right)$, and $\mathrm{t}=$ electroplating time (hr)

\section{Results And Discussion}

\subsection{Inhibitors Efficiency}

By electroplatting process for around 60 minutes with 1 $\mathrm{mol} / \mathrm{L} \mathrm{HCl}$ of solution, it is shown efficiency :

Table 1. Inhibitors Efficiency

\begin{tabular}{|c|c|c|c|c|c|}
\hline \multirow{2}{*}{$\begin{array}{c}\mathrm{t} \\
\text { (time) }\end{array}$} & $\begin{array}{c}\text { without } \\
\text { inhibitor }\end{array}$ & \multicolumn{5}{|c|}{ Inhibitors } \\
\cline { 3 - 6 } & & $2 \mathrm{ml}$ & $2 \mathrm{ml}$ & $4 \mathrm{ml}$ & $4 \mathrm{ml}$ \\
aquadest & methanol & aquadest & methanol \\
\hline 0 & 100 & 100 & 100 & 100 & 100 \\
\hline 10 & 99.74 & 99.66 & 99.60 & 99.66 & 99.89 \\
\hline 20 & 99.47 & 99.47 & 99.36 & 99.50 & 99.71 \\
\hline 30 & 99.15 & 99.16 & 99.14 & 99.23 & 99.37 \\
\hline \multicolumn{5}{|c|}{ Average Efficiency } \\
\hline & 99.59 & 99.57 & 99.52 & 99.60 & 99.74 \\
\hline
\end{tabular}

Table 2. Corrossion Rate (mpy)

\begin{tabular}{|c|c|c|c|c|}
\hline \multirow{2}{*}{$\begin{array}{c}\text { Without } \\
\text { Inhibitor } \\
\text { (mpy) }\end{array}$} & $2 \mathrm{ml}$ aquadest & $2 \mathrm{ml}$ methanol & $4 \mathrm{ml}$ aquadest & $4 \mathrm{ml}$ methanol \\
\hline $1,13 \mathrm{E}-05$ & $1,12 \mathrm{E}-05$ & $1,17 \mathrm{E}-05$ & $1,08 \mathrm{E}-05$ & $8,88 \mathrm{E}-06$ \\
\hline
\end{tabular}

Two table above, it can be seen the value of the efficiency of corrosion rate with and without inhibitors of onion peel extract with various solvents. Efficiency is obtained from the calculation of $\mathrm{w} /$ wo of the electroplated metal. The calculation results show that the average efficiency value using aquadest and methanol solvent inhibitors of $4 \mathrm{ml}$ each yields the highest efficiency. This is due to the presence of flavonoid content of the brown onion peel. According to previous research, flavonoids are most commonly found in plant tissues that act as antioxidants [5]. This antioxidative activity of flavonoids stems from the ability to donate its hydrogen atom or through its ability to choke the metal. In addition, the potential as a corrosion inhibitor because it has a pair of free electrons. these free electron pairs will later be adsorbed on the metal surface so as to protect the metal from corrosion attack [6].

\subsection{Solvent Used in Extraction}

The solvent effect can be shown in fig 1 below. In an inhibitor with a $2 \mathrm{ml}$ variable of methanol solvent and aquadest, the aquadest solvent provides better performance. While the $4 \mathrm{ml}$ variable, methanol give better performance. The components carried on the extraction process are polarized components according to the solvent, so that the type of solvent used may affect the amount of yield produced [7]. Flavonoids are less polar so dissolve in less polar solvents such as methanol and water. Methanol solvent has a small molecular structure capable of penetrating all plant tissues to attract active compounds out [8]. 


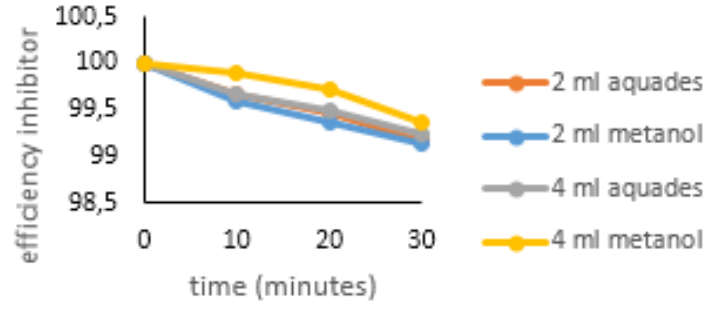

Fig 1. Solvent Extraction Effect

\subsection{HPLC Analysis}

HPLC Analysis recorded with methanol solvent of brown onion peel extract shows in Figure 2 and Figure 3. HPLC analysis propose to know the concentration of flavonoid in brown onion peel extract. Using the 100 ppm of quercetin standard to get the standard curve as a comparison. The quercetin standard detected at 2,44 s and the brown onion peel extract have quercetin at 2,55 s. Comparing to each area, then get the contration of quercetin in brown onion peel extract is $1 \mathrm{mg} / \mathrm{L}$.

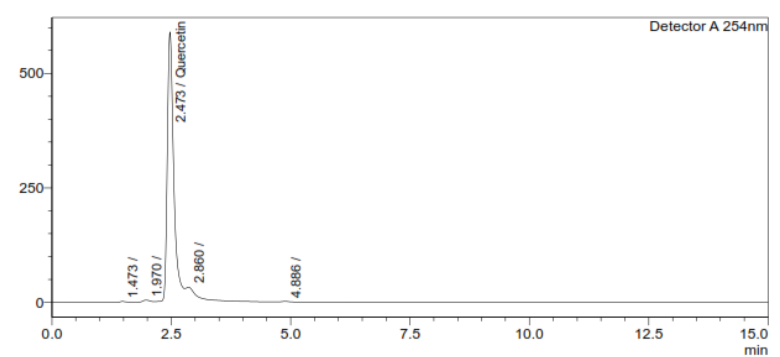

Fig 2. Quercetin Standard

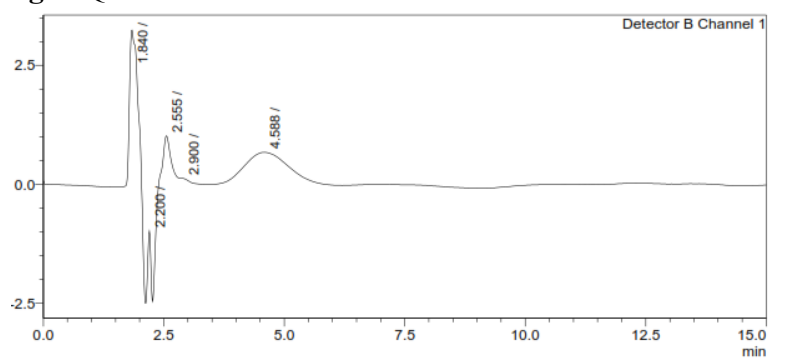

Fig 3. Brown Onion Peel Extract

\section{Conclusion}

Brown onion peel extract shows good efficiency to be green inhibitors in $1 \mathrm{~mol} / \mathrm{L} \mathrm{HCl}$ :

1. In electroplatting process, it is proven that methanol is better than auadest in extracting brown onion due to its polarity.

2. Methanol solvent shows best efficiency with $99,74 \%$ in 30 minutes of $1 \mathrm{~mol} / \mathrm{L} \mathrm{HCl}$ solution.

3. HPLC shown that brown onion peel extract contains $1 \mathrm{mg} / \mathrm{L}$ quercetin which belong to flavonoid group.

\section{Reference}

1. Haryono, Gogot. Ekstrak Bahan Alam sebagai Inhibitor Korosi. Thesis of UPN "Veteran" Yogyakarta: Yogyakarta (2010)

2. Winarsi, Hery, Isoflavon Berbagai Sumber, Sifat dan Manfaatnya Pada Penyakit Degeneratif, (Gadjah Mada University Press, Yogyakarta , 36-43, 2005)

3. Sayuti, Kesuma dan Rina Yenrina. Antioksidan Alami dan Sintetik. Thesis of Andalas University Press: Padang (2015)

4. Fossen, Torgils dan Ingunn Molund Vagen . Onions: A Source of Unique Dietary Flavonoids. Thesis of University of Bergen (2016)

5. Abdi Redha, Flavonoid: Structure, Characteristic Antioxidative and the Function in Biologycal System.. Thesis of Pertanian Politeknik Negeri Pontianak (2010)

6. P. B. Raja, M. G. Sethuraman, Materials Letters, 62, 1, 113-116, 2008.

7. Markham KR. Distribution of flavonoids in the lower plants and its evolutionary significance. (Chapman \& Hall, London, 427-464, 1988)

8. M. H. M. Y. Yuswan, J. R. Al-Obaidi, A. Rahayu, S. Sahidan, F. Shazrul, D. Fauzi, Advances in Bioscience and Biotechnology, 6, 4, 320-329 (2015) 